\title{
The value of double balloon enteroscopy in diagnosing blue rubber bleb naevus syndrome: a case report
}

\author{
Fardod O'Kelly', Kheng Tian Lim', Narayanasamy Ravi ${ }^{1}$, Nasir Mahmud², John V Reynolds ${ }^{\text {* }}$
}

\begin{abstract}
Blue rubber bleb naevus syndrome is a rare vascular disorder associated with multiple gastrointestinal haemangiomas that have the potential for life-threatening haemorrhage. These may be difficult to diagnose, and have classically been described using computed tomographic studies and/or mesenteric angiography. Resected surgical specimens of these lesions, especially in the small bowel, have often been extensive and poorly localized. The recent advent and progressive development of double balloon enteroscopy has allowed the direct visualization and marking of these enteric lesions and serves as a valuable adjunct not only in diagnosis but also planning prior to surgery to allow accurate estimate of the extent of resection.
\end{abstract}

\section{Introduction}

Blue rubber bleb naevus syndrome, also known as Bean Syndrome was first described in 1958 on the basis of 1-2 $\mathrm{cm}$ violaceous cutaneous lesions, is a rare disorder consisting of gastrointestinal vascular malformations, which carry a significant potential for serious haemorrhage. The majority of cases are sporadic, however it has been postulated that this syndrome may manifest as a familial vascular malformation with autosomal dominance and associated with the TEK tyrosine kinase receptor which is almost exclusively endothelial and involved in endothelial-smooth muscle cell signaling [1]. Symptoms and signs depend on the organ system involved, ranging from none to anaemia to overt blood loss which may be massive. Patients may also complain of bone/joint pain, haemoptysis, haematuria or even blindness.

The predominant location of these lesions in the small intestine can make them difficult to diagnose. Double balloon enteroscopy was developed in 2001 as a technique to endoscopically visualize the small bowel in real time and allow therapeutic intervention such as biopsy, dilatation and placement of stents, and it has largely supplanted CT enteroclysis and angiography in the diagnosis of small bowel sources of blood loss [2].

\footnotetext{
* Correspondence: reynoljv@tcd.ie
'Department of Clinical Surgery, Trinity Centre, St James's Hospital, Dublin 8,

*Correspondence: reynoljv@tcd.ie
'Department of Clinical Surgery, Trinity Centre, St James's Hospital, Dublin 8, Ireland
}

(c) 2010 O'Kelly et al; licensee BioMed Central Ltd. This is an Open Access article distributed under the terms of the Creative Commons Attribution License (http://creativecommons.org/licenses/by/2.0), which permits unrestricted use, distribution, and reproduction in any medium, provided the original work is properly cited.

\section{Case presentation}

A 58-year-old female, Irish, Caucasian patient presented, on a background history of chronic anaemia, with fatigue, palpitations, dyspnoea and haemoglobin of $5.4 \mathrm{~g} / \mathrm{dL}$. She had received intermittent blood transfusions during the previous three years. Oesophagogastroduodenoscopy and colonoscopy were normal. She was positive for occult blood. Computed tomography (CT) enteroclysis was performed which demonstrated nodular thickening of the distal jejunum (Figure 1). CT mesenteric angiogram demonstrated multiple subcentimeter hyperenhancing foci identified throughout the jejunum with normal enhancement of the aorta and mesenteric vessels (Figure 2). The patient underwent antegrade double-balloon enteroscopy (DBE) and multiple hypervascular polypoid lesions were found resembling bunches of grapes and extending over a section of $30-40 \mathrm{~cm}$ in the mid-jejunum (Figure 3). The distal margin of this segment was tattood.

The patient underwent a mini laparotomy via a $5 \mathrm{~cm}$ incision, with segmental jejunal resection and primary hand-sewn anastomosis. She made an uneventful postoperative recovery. Histology demonstrated sections of jejunal polyps showing multiple cavernous haemangiomas, many of which showed organizing thrombus. Given the multiplicity, these were consistent with the blue rubber bleb naevus syndrome. 


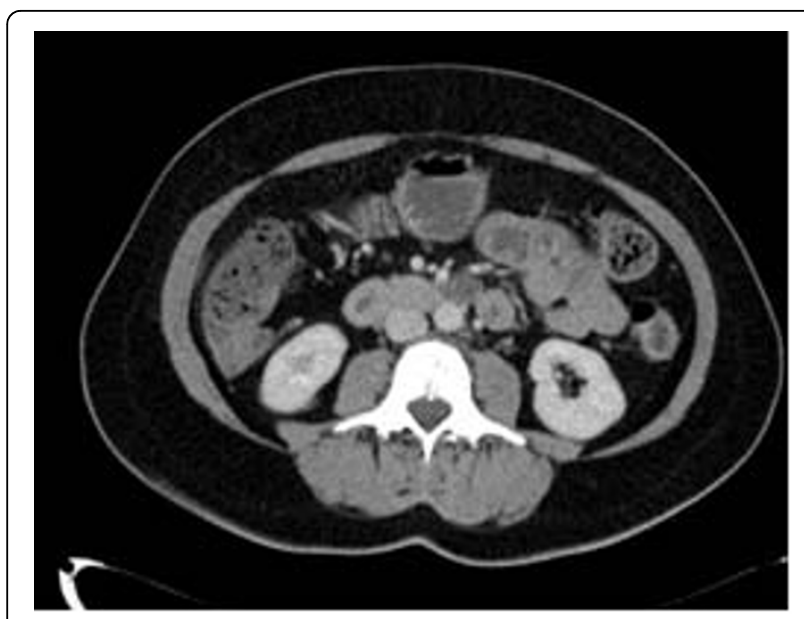

Figure $1 \mathrm{CT}$ enteroclysis demonstrating nodular thickening of the jejunum.

\section{Discussion}

Blue rubber bleb naevus syndromes affecting the gastrointestinal tract are uncommon and, present a diagnostic challenge to those investigating cases of occult gastrointestinal anaemia or haemorrhage. There have been a number of medical modalities employed to treat this condition using anti-angiogenic agents such as corticosteroids, interferon-alpha and octreotide, but to little clinical effect $[3,4]$. Some have cautioned against surgery, predicting that recurrence would occur from naevi in other parts of the gastrointestinal tract [5].

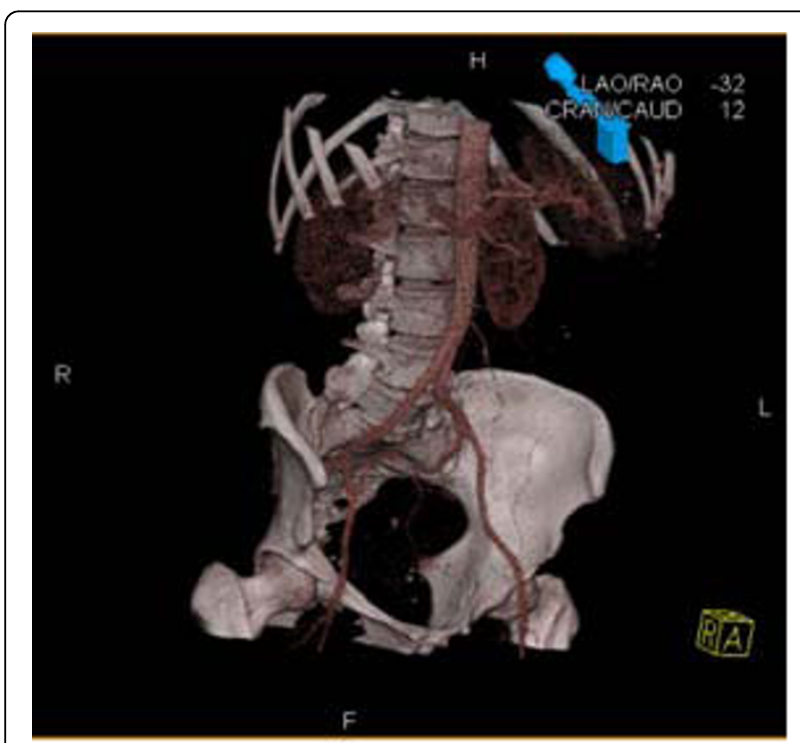

Figure 2 CT mesenteric angiogram demonstrating normal enhancement of intra-abdominal vessels with no active bleeding points but evidence of small vascular anomalies.

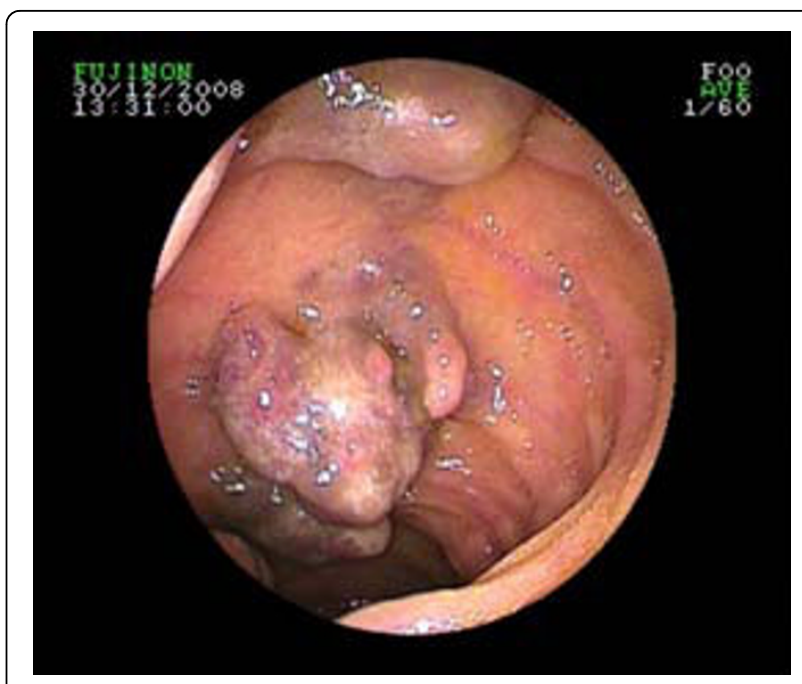

Figure 3 DBE demonstrating presence of multiple areas of vascular abnormalities within the small bowel lumen.

Conversely, in one of few prospective studies on blue rubber bleb naevus syndrome, Fishman et al demonstrated the surgical resection resulted in elimination of bleeding in nine out of ten patients without recurrence over a five year follow-up period [6].

In this report, we highlight the value of DBE in pointing the location and extent of this condition. In a retrospective study by Lin et al, using DBE to identify gastrointestinal blood loss, localization of bleeding was provided in 95\% (53/56) patients, and allowed prompt and accurate surgical resection in all but a single patient [7]. DBE appears to be a safe, useful and important adjunct prior to surgical resection of small bowel lesions including blue rubber bleb naevus syndrome, as it not only allows the precise localization and marking of these lesions, to ensure accurate resection as demonstrated in the above case, but it can also provide pre-operative histological diagnosis. By employing DBE that allows access to those areas of bowel previously only accessible by exploratory laparoscopy or laparotomy, surgical morbidity may also be reduced.

\section{Conclusion}

DBE is a valuable adjunct not only in diagnosis but also planning prior to surgery to allow accurate estimate of the extent of resection.

\section{Consent}

Written informed consent was obtained from the patient for publication of this case report and any accompanying images. A copy of the written consent is available for review by the Editor-in-Chief of this journal. 


\section{Author details}

'Department of Clinical Surgery, Trinity Centre, St James's Hospital, Dublin 8, Ireland. 'Department of Clinical Medicine, Trinity Centre, St James's Hospital, Dublin 8, Ireland.

\section{Authors' contributions}

FOK and KTL drafted the manuscript and prepared the figures. NR, NM and JVR reviewed and amended the manuscript. All authors read and approved the final manuscript

\section{Competing interests}

The authors declare that they have no competing interests.

Received: 15 August 2009

Accepted: 18 January 2010 Published: 18 January 2010

\section{References}

1. Gallione CJ, Pasyk KA, Boon LM, Lennon F, Johnson DW, Helmbold EA,

Markel DS, Vikkula M, Mulliken JB, Warman ML, Pericak-Vance MA,

Marchuk DA: A gene for familial venous malformations maps to chromosome 9p in a second large kindred. J Med Genet 1995, 32:197-199.

2. Yamamoto H, Sekine Y, Sato Y, Higashizawa T, Miyata T, Lino S, Ido K, Sugano K: Total enteroscopy with a nonsurgical steerable double-balloon method. Gastrointest Endosc 2001, 53:216-220.

3. Boente MD, Cordisco MR, Frontini MD, Asial RA: Blue rubber bleb nevus (Bean Syndrome): evolution of four cases and clinical response to pharmacologic cases. Paediatr Dermatol 1999, 16:222-227.

4. Gonzalez D, Elizondo BJ, Haslag S, Buchanan G, Burdick JS, Guzzetta PC, Hicks BA, Andersen JM: Chronic subcutaneous octreotide decreases gastrointestinal blood loss in blue rubber bleb naevus syndrome. $J$ Paediatr Gastroenterol Nutr 2001, 33:183-188.

5. Sandhu KS, Cohen H, Radin R, Buck FS: Blue rubber bleb nevus syndrome presenting with recurrences. Dig Dis Sci 1987, 32:214-219.

6. Fishman SJ, Smithers CJ, Folkman J, Lund DP, Burrows PE, Mulliken JB, Fox VL: Blue rubber bleb nevus syndrome: surgical eradication of gastrointestinal bleeding. Ann Surg 2005, 241:523-528.

7. Lin MB, Yin L, Li JW, Hu WG, Qian QJ: Double-balloon enteroscopy reliably directs surgical intervention for patient with small intestinal bleeding. World J Gastroenterol 2008, 14:1936-1940.

doi:10.1186/1757-1626-3-29

Cite this article as: O'Kelly et al.: The value of double balloon enteroscopy in diagnosing blue rubber bleb naevus syndrome: a case report. Cases Journal 2010 3:29.

Publish with Biomed Central and every scientist can read your work free of charge

"BioMed Central will be the most significant development for disseminating the results of biomedical research in our lifetime. "

Sir Paul Nurse, Cancer Research UK

Your research papers will be:

- available free of charge to the entire biomedical community

- peer reviewed and published immediately upon acceptance

- cited in PubMed and archived on PubMed Central

- yours - you keep the copyright 